\title{
Archaeological Activity in Kabul
}

\section{EXCAVATIONS SINCE 2002}

The role of Kabul is very important for understanding the commercial, cultural, and religious dynamics that have developed in the southern part of Afghanistan. The city was, indeed, a crossing point between Gandhara and Bactria, south to north, and a key crossroads, especially from the late 4th century CE until $1038 \mathrm{CE}$, when the Ghaznavid military attack. The latter resulted in a political and economic upheaval, and perhaps also marked the beginning of the gradual Islamization of Kabul, although no archaeological evidence for that is older than the $13^{\text {th }}$ century. Buddhism and Hinduism have developed side by side in Kabul and sparked the development of a local art school. Thus, we consider Kabul as the second great artistic, cultural, and religious centre after Hadda, in the southern part of the foothills of the Hindu Kush, as evidenced by archaeological excavations such as Khair Khana (1934), Tepe Maranjan (1936 and 1984; see Hackin, Carl, \& Meunié 1959), Tepe Khazana (1936), ${ }^{1}$ Khwaja Safa (see Paiman 2005), Qol-e-Tut, Tepe Narenj (see Paiman 2005; 2006; 2008; 2010), and the results of our excavations in Kabul.

The twenty-five years of war in Afghanistan have had tragic consequences in human terms, but also cultural terms. However, after the fall of the Taliban and the return of relative calm since 2002, the Afghan government, in parallel with rural development and reconstruction of the country, has asked the management of the Archaeological Institute, through the Ministry of Information and Culture, to resume field activities.

In 2002, at my request, the Afghan Institute of Archaeology launched a major archaeological prospection on the entire territory, and in 2004 excavation operations started and the responsibility was given to me.

For the implementation of the census of archaeological sites and historical monuments that have been the subject of looting during the civil war, I set two goals: first, to survey the northern provinces of the Hindu Kush; secondly, to identify monuments and sites looted in the southwest and central Afghanistan, that is to say in the regions of Sistan of Helmand, Kandahar, Ghazni, and Bamiyan. ${ }^{2}$ In 2003 and 2004, I continued the inventory of archaeological sites in the south of the Hindu Kush, and in 2004 two search operations have been launched, under my leadership, at the sites of Khwaja Safa and Tepe Narenj. ${ }^{3}$

After re-opening in 2003, the Délégation Archeologique Française en Afghanistan (DAFA) resumed its archaeological activity in the ancient city of Balkh (Bactres), at Tepe Zargaran, $1.5 \mathrm{~km}$ to the southeast, and on the Achaemenind period site of

\footnotetext{
${ }^{1}$ The Kabul Museum has thirty clay statuettes from this site. See also Schlumberger \& Curiel 1953, p. 129, and Fussman, Murad, \& Ollivier 2008.

${ }^{2}$ Unfortunately, lack of funding, this census operation sites and monuments could be partially conducted. The reports of my surveys were deposited at the direction of the Afghan Institute of Archeology in 2003.

${ }^{3}$ Due to the presence of graves at the site, which could not be moved, we have not been able to implement our excavations on the site of Khwaja Safa.
} 
Chesmeh Shafa located approximately $24 \mathrm{~km}$ south of Balkh, under the direction of Roland Besenval and Philippe Marquis, and as well as in Bamiyan, under the direction of Zemaryalaï Tarzi.

In 2003, an Italian team resumed work on the Buddhist archaeological site of Tepe Sardar in Ghazni province. Unfortunately, due to a lack of either financial means or security, the team was unable to prolong its research. Nevertheless, the Italian conservators restored objects discovered at Tepe Sardar and deposited them in the museums of Kabul and Ghazni. In 2004, German and Japanese archaeologists also began field studies in the Kabul area, Herat, and Bamiyan.

Our survey operations in the southern and northern foothills of the Hindu Kush also allowed us to record previously unknown archaeological sites dating to the period of the Hephtalite kingdom; we hope to study and publish these in the future. Moreover, if many historical monuments and pre-Islamic and Islamic archaeological sites in Afghanistan were subject to looting during the civil war, that is to say between 1992 and 2001, by local traffickers and foreigners, specifically those of neighboring countries, it should be noted that since the last decade the looting of cultural artifacts in Afghanistan decreased by $85 \%$. This decline is largely thanks to the efforts of Afghan colleagues and the local population who often spontaneously monitor archaeological sites located near their village and protect them from looters by warning the authorities when these sites come under threat.

\section{RELIGIOUS HISTORY OF KABUL}

At an altitude of $1800 \mathrm{~m}$, the history of the city of Kabul is not very well known by historians and archaeologists. According to archaeologists of the $20^{\text {th }}$ century, the first religious and civillian installations in the hills surrounding the area are dated to between the mid 1 st and early $2^{\text {nd }}$ century CE. Recent archaeological research and the study of historical monuments that have escaped natural and human destruction has shown that the first religious facilities in the hills surrounding this town date from the late $4^{\text {th }}$ century $\mathrm{CE}$, though the archaeological evidence for these is lacking. Archaeology can confirm that Kabul as we know it dates to at least the $5^{\text {th }}$ century CE, and during the reign of the Hephtalites became a stronghold, important in the history of Afghanistan, and an administrative capital of the southern part of the Hephtalite kingdom and one of the most prestigious economic and religious centres.

Buddhism underwent a remarkable development and, along with Hinduism, was protected by the Hephtalite kings. Parallel to these two religious traditions, from the late $7^{\text {th }}$ century onward, a Tantric current was also adopted by the population in Kabul. Excavations of four Buddhist monasteries ${ }^{4}$ by the Afghan Institute of Archaeology, between 2004 and 2014, under my leadership, and the excavations of DAFA in the 1930s at the sites of Kohtal-e-Khair Khana, Tepe Khazana, and Tepe Maranjan, testify to this remarkable religious past. Then, according to the ancient writings from the destruction of the city by the Ghaznavids in the early $11^{\text {th }}$ century, and the ascendency to power of the Timurids in the $15^{\text {th }}$ century, Kabul was reduced to the size of a small market town.

\footnotetext{
${ }^{4}$ Khwaja Safa, Kunjakaï, Tepe Narenj, and Qol-e-Tut.
} 
The writings of Arab historians such as Al Balazuri, Ya'qubi, (d. 897), Masudi (10 ${ }^{\text {th }}$ century), Ibn al-Athir (1160-1233), or those of later Persian historians such as Bayhaqi ( $10^{\text {th }}$ century), Gardizi ( $11^{\text {th }}$ century), the unknown author of the history of Sistan (late $10^{\text {th }}$ century), Juzjani $\left(13^{\text {th }}\right.$ century), and Qazwini $\left(13^{\text {th }}\right.$ century), reported that city residents accepted Islam early in the second half of the $7^{\text {th }}$ century. Yet the archaeological research in the southern and central part of Afghanistan demonstrate the devastating first incursion of the Islamic Army in the late $9^{\text {th }}$ century, not the $7^{\text {th }}$ century, under the command of Yaqub bin Layth Saffar. The history of Sistan says that in the year 256 of the Hegira, that is to say, in $877 \mathrm{CE}$, Yaqub after the destruction of Balkh (Bactres) and Bamiyan, targeted Kabul. ${ }^{5}$ However, our archaeological discoveries since 2004 confirm that the first Islamic incursion in Kabul was in the late $9^{\text {th }}$ century. Al Biruni, astronomer, historian, and geographer (973$1050 \mathrm{CE}$ ) who accompanied Mahmud of Ghazni on his expeditions in India, reflects on the military and political relations between the Hindu-Shahi kingdom and the Ghaznavids. ${ }^{6}$ This testimony is particularly valuable because it is the only one that is direct and trustworthy. He writes:

"The Hindus had kings residing in Kâbul, Turks who were said to be of Tibetan origin. The first of them, Barhatakîn, came into the country and entered a cave in Kabul, which none could enter except by creeping on hands and knees. The cave had water, and besides be deposited there victuals for a certain number of days. It is still known in our time, and is called Var. People who consider the name of Barhatakin as a good omen enter the cave and bring out some of its water with great trouble.

Certain troops of peasants were working before the door of the cava Tricks of this kind can only be carried out and become notorious, if their author has made a secret arrangement with somebody else in fact, with confederates. Now these had induced persons to work there continually day and night in turns, so that the place was never empty of had entered the cave, he began to creep out of it in the presence of the people, who looked on him as a new-born baby. He wore Turkish dress, a short tunic open in front, a high hat, boots and arms. Now people honored him as a being of miraculous origin, who had been destined to be king, and in fact he brought those countries under his sway and ruled them under the title of a shâhiya of Kâhul. The rule remained among his descendants for generations, the number of which is said to be about sixty. Unfortunately the Hindus do not pay much attention to the historical order of things, they are very careless in relating tiie chronological auccession of their kings, and when they are pressed for information and are at a loss, not knowing what to say, they invariably take to tale-telling. But for this, we should communicate to the reader the traditions which we have received from some people among them. 1 have been told that the pedigree of this royal family, written on silk, exists in the fortress Nagarkot and 1 much desired to make myself acquainted with it, but the thing was impossible for various reasons. One of this series of kings was Kanik, the same who is said to have built the vihâra (Buddhistic monastety) of Purushâvar. It is called, after him, Kanik-caiya, people relate that the king of Kanoj had presented to him, among other gifts, a gorgeous and most singular piece of cloth. Now Kanik wanted to

\footnotetext{
${ }^{5}$ History of Sistan, in Persian, 1366/1987, p. 215-216.

${ }^{6}$ To better understand the military and political relations of the Kingdom of Kabul with the Ghaznavids in the late 10th century, we reproduce the full text of Al Biruni, translated from Arabic into English by C. Sachau, yet curiously remained virtually unknown.
} 
have dresses made out of it for himself, but his tailor had not tlie courage to make them, for he said,' there is (in the embroidery) the figure of a human foot, and whatever trouble I may take, the foot will always lie between the shoulders.' And that means the same as we have already mentioned in the story of Bali, the son of Virocana (i.e. a sign of subjugation, cf. i. p. 397). Now Kanik felt convinced that the ruler of Kanoj had thereby intended to vilify and disgrace him, and in hot haste he set out with his troops marching against him. When the râî heard this, he was greatly perplexed, for he had no power to resist Kanik. Therefore he consulted his Vazir, and the latter said, 'You have roused a man who was quiet before, and have done unbecoming things. Now cut off my nose and lips, let me be mutilated, that I may find a cunning device; for there is no possibility of an open resistance.' The râi did with him as he had proposed, and then he went off to the frontiers of the realm. There he was fonnd by the hostile army, was recognised and brought before Kanik, who asked what was the matter with him. The Vazir said 'I tried to dissnade him from opposing you, and sincerely advised him to be obedient to yon. He, however, conceived a suspicion against me and ordered me to be mutilated. Since then he has gone, of his own accord, to a place which a man can only reach by a very long journey when he marches on the highroad, but which he may easily reach by undergoing the trouble of crossing an intervening desert, supposing that he can carry with himself water for so and so many days.' Thereupon Kanik answered: 'The latter is easily done.' He ordered water to be carried along, and engaged the Vazir to show him the road. The Vazir marched before the king and led him into a boundless desert After the number of days had elapsed and the road did not come to an end, the king asked the Vaziîr what was now to be done. Then the Vazir said, 'No blame attaches to me that I tried to save my master and to destroy his enemy. The nearest road leading out of this desert is that on which you have come. Now do with me as you lik, for none will leave this desert alive.' Then Kanik got on his horse and rode round a depression in the soil. In the centre of it he thrust his spear into the earth, and lo! water poured from it in sufficient quantity for the army to drink from and to draw from for the march back. Upon this the Vazir said, 'I had not directed my cunning scheme against powerful angels, but against feeble men. As things stand thus, accept my intercession for the prince, my benefactor, and pardon him.' Kanik answered, 'I march back from this place. Thy wish is grunted to thee. Thy master has already received what is due to him.' Kanik returned out of the desert, and the Vazir went back to his master, the râî of Kanoj. There he found that on the same day when Kanik had thrust his spear into the earth, both the hands and feet had fallen off the body of the rdâi. The last king of this race was Lagatûrmân, and his Vazir was Kallar, a Brahman. The latter had been fortunate, in so far as he had found by accident hidden treasures, which gave him much influence and power.

In consequence, the last king of this Tibetan house, after it had held the royal power for so long a period, let it by degrees slip from his hands. Besides, Lagatûrmân had bad manners and a worse behaviour, ou account of which people complained of him greatly to the Vazîr. Now the Vazîr put him in chains and imprisoned him for correction, but then he himself found ruling sweet, his riches enabled him to carry out his plans, and so he occupied the royal throne. After him ruled the Brahman kings Sâmand (Sâmanta Deva), Kamalû, Bhim (Bhimapâla), Jaipâl (Jayapâla), Ânandapâla, Tarojanapâla (Trilocanapâla). The latter was killed A.H., 412 (A.D. 1021 «1033»), and his son Bhîmapâla five years later (a.d. 1026 «1038»). This Hindu Shâhiya dynasty is now extinct, and of the whole house there is no longer the slightest remnant in existence. We must say that, in all their grandeur, they never slackened in 
the ardent desire of doing that which is good and right, that they were men of noble sentiment and noble bearing. I admire the following passage in a letter of Ânandapâla, which he wrote to the prince Mahmûd, when the relations between them were already strained to the utmost; 'I have learned that the Turks have rebelled against you and are spreading in Khurâsân. If you wish, I shall come to you with 5000 horsemen, 10,000 foot-soldiers, and 100 elephants, or, if you wish, I shall send you my son with double the number. In acting thus, I do not speculate on the impression which this will make on you. I have been conquered by you, and therefore I do not wish that another man should conquer you.' The prince cherished the bitterest hatred against the Muhammadans from the time when his son was made a prisoner, whilst his son Tarojanapâla (Trilocanapâla) was the very opposite of his father" (Sachau 1888).

The historical record indicates that Kabul remained occupied by the Hindu-Shahi kings until the early $11^{\text {th }}$ century, as confirmed by the coins found dating back to the Shahis on the sites of Tepe Narenj and Qol-e-Tut.

The gradual Islamization of Kabulistan, and its capital Kabul, only begins, according to both archaeological data and the testimony al Biruni, with the rise of the Ghaznavid Empire after Bhima Pala's death in 1038 CE. Archaeology shows the destruction of civil and religious monuments of the city, following the progressive installation of Muslims in the city of Kabul, and marking the end of an empire that reigned in peace with respect to all religions. Furthermore, the size of the city was also diminished.

\section{THE BUDDHIST MONASTERY OF TEPE NARENJ}

The site of Tepe Narenj, or "hill of orange trees," was the name given by the locals, and is not mentioned in the texts, either ancient or modern. It is not mentioned in any ancient texts of Chinese pilgrims, nor in the writings of Arabic and Persian historians. Only the location of an archaeological site is mentioned in the writings of the $20^{\text {th }}$ century, without any clarification in the name of ziyarat Panj-e-Shah. ${ }^{7}$ Only Charles Masson, keen numismatics explorer, alludes to a site named Panja Shâh Merdân that he visited during his stay in Kabul in the 1830s.

“[.....] Without asking permission of any one, I commenced an operation upon a mound at the skirt of the hill Koh Takht Shâh, separated by a spur from the ziárat Panjah Shâh Merdân. It was at the entrance of a little khol, or glen, called Khol Shams, where was a spring and a few trees. The spot I had often visited with picnic parties. Below, or east of it, was a castle and garden, belonging to Akhund Iddaitulah $\left[\ldots . . . . "{ }^{\prime \prime}\right.$

Indeed, a ziyarat named Panja-e-Shah is on the south side, at the foot of the hill of the Tepe Narenj monastery.

\footnotetext{
${ }^{7}$ Curel \& Schlumberger 1953, p. 130; Dupree, 1965, p. 93; Ball \& Gardin, 1982, p. 121, No. 418. Knowing that, in these references, the site is only mentioned as the Kol-e Hashmat Khan or Shah-iPanja, no further details on the nature of the site. According to the stories of the inhabitants and the writings of Mohammad Ibrahim Khalil, the ziyarat date of the early $20^{\text {th }}$ century about (Mohammad Ibrahim Khalil 1339 (1950), Mazarat-e Shahr-e Kabol, p. 39 in (Persian).

${ }^{8}$ Masson 1844, pp. 94-95.
} 


\section{SITE DESCRIPTION}

Tepe Narenj hill, where the main monastery was located, is $1.69 \mathrm{~km}$ in a beeline south of the Bala Hisar (citadel). Built on the slope of the mountain of Koh-e-Zanbourak ("Zanbourak Mountain "), it is bounded from the north and south by two ravines, and the east side by the road giving access to the ziyarat and Tepe Narenj. The highest side (Zone II) is at an altitude of $1935 \mathrm{~m}$, and the lowest at $1875 \mathrm{~m}$. The monastery, originally extended continuously over more than 300 meters from east to west, and 60-140 m wide, depending on location. ${ }^{9}$

The site was supplied with water from the Hashmat Khan Lake and a water source located further down, on the south side of the hill of Tepe Narenj, where was built in the beginning of the 20th century, the ziyarat of Panja-e-Shah. Our excavations started on the upper part of the monastery. The typology of the hill did not permit to use a grid, and so the site was divided into twelve areas, as the excavations moved forward, between 2004 and 2013. The site includes three levels, lower, middle, and upper (Paiman \& Alram 2013). ${ }^{10}$ The lower level is less than $14.5 \mathrm{~m}$ from the middle. All of these developments are oriented towards the east. Areas X, XIII, and XIV are located outside the perimeter of the hill of Tepe Narenj.

From bottom to top, we have:

Area VIII, marked by four successive niches.

Area VII, with three cells and chapels of various sizes.

Area $\mathrm{V}$, occupied by four rectangular bases of various sizes and heights.

Area IX, where a long staircase of $19.50 \mathrm{~m}$ connects the lower and upper parts; plus six bases of various lengths.

Area VI, occupied by a large stupa of 10,60 square meters.

Area III with five chapels.

Area IV, which was the junction between the middle and upper portion, through which a $28 \mathrm{~m}$ long staircase and having the residues of two small stupas.

Area XI on the highest part of the monastery with a chapel (CH 6).

Area I having six columns (?) of various diameters.

Area II placed in the far west, the highest of the monastery, with a circular room with a central hall.

I will limit the scope of this article to a brief description of Tepe Narenj-not of the entire site, but only of buildings of areas II, III, X and XI, ${ }^{11}$ without insisting on the various stages of development of the monastery.

\section{$\underline{\text { Zone II }}$}

\footnotetext{
${ }^{9}$ Today, this large monastery is divided into four groups of facilities, namely, 1 the main hill or top, called Tepe Narenj, 2-zone X, at a distance of 110 m southeast, 3 - XIII area, 51 meters north of Tepe Narenj, 4- XIV area, which is under a cemetery on the east side of the road giving access today to the hill of Tepe Narenj.

10 These three levels are studied under the name terraces.

${ }^{11}$ For more details on the architecture and sculpture of the monastery, see Paiman \& Alram 2013.
} 
Zone II is bordered to the north and south by a ravine. We reached this level from the East, with a staircase linking the Zone I, II, and XI areas. The developments of Zone II are located at the top of the monastery. They have three squared cells of various sizes $(3.25 \times 4.39 \mathrm{~m}-3.26 \times 3.04 \mathrm{~m}$ and $2.85 \times 2.89 \mathrm{~m})$, built on the north side of the area and open to the south. There is also a circular room on the west side with three niches; four others are visible from the outside. All of these developments are built on an artificial terrace (T9), of $21.90 \mathrm{~m}$ long (E-W), $13.40 \mathrm{~m}$ wide (N-S) and raised 2.20 $\mathrm{m}$ off of the ground level of Zone 2 .

\section{The Circular Room}

Considered as a room dedicated to homa (fire sacrifice), the Circular Room marks the western boundary of the monastery complex. It opens to the north and is the most important edifice in this area. With a diameter of $5.33 \mathrm{~m}$, it includes on the west side a semicircular bench of mud brick, $60 \mathrm{~cm}$ deep and $52 \mathrm{~cm}$ high. The inside of the room, enclosed by thick walls of $1.90 \mathrm{~m}$, was painted dark red. It is accessible from the terrace by a corridor of $5.56 \mathrm{~m}$ long and $1.20 \mathrm{~m}$ wide. The center of the room is occupied by a circular hearth of $82 \mathrm{~cm}$ in diameter, whose circumference is burnt at a $10 \mathrm{~cm}$ depth. It sits above an octagonal base of $1.10 \mathrm{~m}$ in diameter. Like most of the monuments of the site, the buildings of this area were not spared from the damage caused by man and nature. During the course of the excavations, we noticed, for example, that the destruction of the retaining wall on the south side of the terrace was caused by a landslide; but the destruction of the cells on the north side and a part of the circular room was deliberately caused by man. It should be noted that this room is the first discovery of this kind in the city of Kabul and its region.

\section{Zone III}

This area is occupied by the terrace T5 and is located in the far west of the middle part of the site. It is $35.77 \mathrm{~m}$ wide and $14.63 \mathrm{~m}$ deep. The terrace is divided into five successive levels from east to west, and it is on the highest level that the five chapels open to the east (Figure 1 and map) are built, which are accessible by stairs located on lower levels. We limit the description of the chapels to $\mathrm{CH} 2, \mathrm{CH} 3$, and $\mathrm{CH} 4$, as the $\mathrm{CH} 1(5.69 \times 4.72 \mathrm{~m})$ and $\mathrm{CH} 5(4.48 \times 4.24 \mathrm{~m})$ are almost completely deteriorated.

\section{Chapel CH 2}

It measures $5.05 \times 4.29 \mathrm{~m}$, and is separated, on the south side, from the chapel $\mathrm{CH} 1$ by a thick wall of $1.71 \mathrm{~m}$; the north wall is $2.73 \mathrm{~m}$ thick, and the one in the back is $1.52 \mathrm{~m}$. These walls are made of a stone foundation, topped by mudbricks of $38 \times 38$ $\mathrm{x} 8 \mathrm{~cm}$. The walls are protected by a coating layer of clay mixed with straw and a yellow layer of clay. It should be added that the back walls of the five chapels are reinforced with a second stone wall, $1.10 \mathrm{~m}$ thick.

The CH 2 chapel was closed by a door placed at the end of a corridor of $1.94 \mathrm{~m}$ long and $1.80 \mathrm{~m}$ wide. The center of the chapel is occupied by a square stupa of $2.06 \mathrm{~m}$ wide, built in stone slats. All that remains of its original height is $2.80 \mathrm{~m}$. In a very original typology architecturally, it is an unparalleled and unique form to date, not only in Afghanistan but also in the Buddhist world (Fig. 2; see Fussman, Baba Murad, \& Ollivier 2008: 87; Paiman \& Alram 2013: 46-48). There are four massive columns connected by arches $55 \mathrm{~cm}$ deep located at the four cardinal points. Under these sat four of the five transcendent Buddhas (jina), as evidenced by the bases, $12 \mathrm{~cm}$ high, 
as well as sculptural remains. The jinas relied on the squared central pillar of $50 \mathrm{~cm} .^{12}$ This iconography evokes the stage of the Tantric Buddhism, present on Afghan soil from the late 7th or early 8th century (see Tarzi 1976: 406-407, 410; Paiman 2005: 35; Paiman \& Alram 2013: 48).

\section{Chapel CH 3}

The chapel, measuring $4.85 \times 3.80 \mathrm{~m}$, is open over its entire width of the east side. A base of mud bricks, $80 \mathrm{~cm}$ high and $1.52 \mathrm{~m}$ deep, is placed against the back wall. We have identified there the bottom of a monumental clay Buddha, sitting cross-legged facing the entrance. The distance between his knees being $3.02 \mathrm{~m}$, it is currently the largest sitting Buddha unearthed in the Kabul area. On the same base, to the right of the Buddha, we discovered a bodhisattva Vajrapani. ${ }^{13}$ On the benches, $5 \mathrm{~cm}$ high, arranged against the side walls of the chapel, we have unearthed the remains of six other characters, also in clay, represented side by side, three on the left and three on the right (Fig. 3): on the south seat, going to the back, a bodhisattva of a monumental size, with feet $43 \mathrm{~cm}$ long, alongside a secular character dressed in a coat (chapan) and boots, whose style resembles that of northern Afghanistan and Central Asia; then a third person, shirtless and wearing a drape around the waist, stands against the base of the Great Buddha. Against the seat in front of it, there is a bodhisattva almost identical size to the one in the south, with feet measuring $40 \mathrm{~cm}$, another lay wearing boots, and, finally, a character with particularly refined look, the left knee on the floor, the right knee raised, leaning against the wall of the base where stands the Buddha. Its close proximity to the Buddha reminded that it was a devotee of royal origin; over his head, wearing a tiara adorned with three crescents embellished with beads, was discovered in Chapel $\mathrm{CH} 4$.

\section{Chapel CH 4}

In the continuation of the three chapels on the north side of the terrace, Chapel 4 has the distinction of being circular (diameter: $6.70 \mathrm{~m}$ ). Its shape and interior evokes a mandala: indeed, the bench in mud bricks along the wall supported sixteen colossal clay sculptures standing, whose bare feet measure 35 to $42 \mathrm{~cm}$ (Fig. 4). We have unearthed one of these sculptures almost in its entirety. The body was shifted to the ground and the head was damaged. It measures $2.92 \mathrm{~m}$, but if we add the ankles and feet kept on the bench, it reaches a height of $3.08 \mathrm{~m}$. It wears a bracelet and a necklace.

The center of the chapel is occupied by a rectangular base of $1.48 \times 1.30 \mathrm{~m}, 1 \mathrm{~m} \mathrm{high}$, resting on a rectangular base of $1.59 \times 1.41 \mathrm{~m}$. Given its size, this base was designed for a small statue, probably of metal, because no trace of clay remains at this location. The sixteen statues were probably bodhisattvas, distributed circularly around a Buddha, perhaps Vairocana, and this tends to confirm the presence of Tantric Buddhism in Kabul at that time.

\section{Zone XI, CH 6 Chapel}

\footnotetext{
${ }^{12}$ Regarding stupa containing jina, see Bénisti 1960: 83.

${ }^{13}$ This character reminds us Vajrapani V2 niche of large vihara Tepe Shotor at Hadda (Jalalababd region) at $125 \mathrm{kms}$ east of Kabul: see Tarzi 1976, pp. 394-396 and figs. 10-11. The site of Tepe Shotor was destroyed in 1992 by fanatics, and I was able to see it firsthand in 1993.
} 
A rectangular terrace (T7) $20.18 \mathrm{~m} \times 13 \mathrm{~m}$, located $28 \mathrm{~m}$ and $16 \mathrm{~m}$ above the chapel mentioned above, is divided in two by a staircase $8.60 \mathrm{~m}$ long and $1.40 \mathrm{~m}$ wide. During our search, we have not found a trace of any adjustments on the north side of the terrace. In contrast, significant elements have emerged in its southern part. There were three bases, one of which has disappeared except a few stones of its foundation. All were housed in a chapel $(\mathrm{CH} 6)$ open to the east. The bases rest against benches made in mudbricks, which themselves were placed against the walls of the building. We were able to identify the central base, at the bottom of the chapel, the remains of the feet $(71 \mathrm{~cm} \times 25 \mathrm{~cm})$ of a monumental bodhisattva in yellow clay, covered with a layer of red clay (Fig. 5). Given its size and the position of his feet, the statue was standing against the seat set behind the base, probably measured between 4.50 and 5 meters high.

\section{Zone X, CH Chapel 8}

This area is located $110 \mathrm{~m}$ southeast and outside the perimeter of the hill of Tepe Narenj. The excavation of this small mound allowed us to discover a chapel $4.68 \mathrm{~m} \mathrm{x}$ $4.11 \mathrm{~m}$, open to the north. On the south side, it leans against the slope of Koh-eZanbourak reinforced by a double wall, $1.58 \mathrm{~m}$ and $1.75 \mathrm{~m}$ thick. The floor of the chapel was entirely covered with a layer of stucco. Its interior had five rectangular bases, the main one being in the center, opposite the entrance. It measures $1 \times 1.89 \mathrm{~m}$ and supported a sculpture standing in yellow clay that was also covered by a layer of red clay. The only remains were gigantic feet, measuring $94 \mathrm{~cm}$ long, and a small part of its multi-colored drapery (blue, red, and yellow) was heavily damaged. On the base located on the east side, $45 \mathrm{~cm}$ high, there is a left foot $(77 \mathrm{~cm})$ of another clay statue that was standing on a pedestal; however, the height of the pedestal disposed on the west side is only $38 \mathrm{~cm}$, and there is no trace of any sculpture (Fig. 6).

\section{RESTORATION AND PROTECTION (Figs. 7, 8, 9)}

Despite the lack of developments as spectacular as Tepe Shotor (Hadda), Tepe Sardar (Ghazni), and Mes-e Aynak, Tepe Narenj allowed us to open a new page of the knowledge of Buddhism in Kabul, but also to illustrate a major artistic development in the southern part of Afghanistan.

The excavation of Tepe Narenj also marked a significant step in the renaissance of Afghan archaeology. After long years of war, these excavations were one of the first opportunities to train Afghan students in archaeology, and so they were invited to work on the site during certain periods.

We must remember that it is thanks to the reporting of one of the inhabitants of this area, to the Afghan Institute of Archaeology, after he had seen ancient walls emerging during the construction of a house. It had been known by the Institute that a Buddhist site existed at this location, but the community intervention was an important part of the process toward the excavation and, thus, preservation of the site of Tepe Narenj. It seems that, on this subject, it is important for the future to ensure that there is cooperation of the local people in the rescuing of archaeological heritage. However, they remain in many cases kept out of the excavations. A dialogue with local residents to inform them during the excavations would contribute very positively to this effort. Some of the people working with us for many years in Tepe Narenj belong to local 
families, which greatly facilitated the dialogue and permits, for example, to move modern graves that were located on the old site.

Tepe Narenj is one of the many Buddhist sites whose traces remain in Kabul and its region. Some have been subject to illegal excavations, either looted or destroyed, and the majority of them have not yet been formally excavated by archaeologists. All of this makes the discoveries made so far on the site more valuable in what they can contribute to the knowledge of the history and art of Buddhism in Kabul.

The eleven excavations, carried out under my direction between 2004 and 2013 with the support of the Afghan Institute of Archeology, show activities that happened between the $5^{\text {th }}$ and $11^{\text {th }}$ centuries $\mathrm{CE}$ and have many original features on the architectural, technical, and artistic side. This very long period of occupation shows that Buddhism continued to exist in Kabul much longer than previously thought. From our first campaign, we have consolidated the sculptures and walls as they appeared, with the help of restorers of the Kabul Museum and the Institute of Archaeology. We also protected the buildings of the site with roofs, which, unfortunately, is not always the method used on other important sites excavated between 2003 and 2013 by foreign archaeologists, where monuments are simply covered with a tarp!

All the sculptures discovered at Tepe Narenj were consolidated using available products, including paraloid. This has reinforced the outer surface of the statues, but their internal and final consolidation will require a significant financial investment and hiring a professional caterer practiced in this technique. On top of this, we consolidated fragments of stucco coating that remained on the walls of the stupa of the CH 2 Chapel (Zone III). They were reattached with glue and a mixture of clay and stucco, as well as the stucco layers covering the drapery of the statues. Some of the sculptures have sometimes required urgent restoration. For this, after having dusted extremely fragile sculptures of the chapels, we used yellow clay from certain other pieces of sculptures that were totally destroyed.

We have also made a lasting protection in two stages, with very modest financial means at our disposal:

1- Building roofs, essential to protect the sculptures, above the chapels of III, the circular room of area II, and the chapels in the X and XI areas.

2- Consolidation of the retaining walls and stairs.

Our first concern was to choose between a tin roof or a flat and adobe traditional roof, used today in the city of Kabul, and then selecting building materials, either raw or baked bricks and metal or wooden beams. To maintain the original style of all the buildings would have required building cupola roofs, but our financial resources did not allow us to implement such a project. We hope in the future to realize it. On top of that was the problem of the cost to transport all of these elements to the chapels and the circular room of the homa, located approximately $80 \mathrm{~m}$ higher compared to the path to the site. Our other concern was to conduct the necessary masonry work without distorting and changing the nature of the ancient walls. Upon reflection, we decided to first apply a layer of clay mixed with straw (traditional materials in 
Afghanistan) over the existing walls before adding on top of these, new walls of baked bricks. ${ }^{14}$ It should be added that due to the various sizes of buildings and fragile sculptures, we used two masonry methods.

First, concerning the chapels, the new walls built over the ancient ones were voluntarily narrower. On the walls, a coating layer composed of clay and straw has been applied, before the introduction of metal beams for the construction of the roofs. Second, for the circular room of the homa, we applied a completely different method, building brick pillars. To better preserve the originality of the ancient walls, the pillars for the roof supports were placed directly on the top of the walls and on the floor of the room that were covered with a layer of clay, then pillars are also covered with a clay layer. After completing the roofs, the terraces in front of the chapels of Area III were consolidated by strengthening the existing stone walls or building new stone walls where necessary. The old stairs have been protected with stone slabs. We also took care to delineate the site by installing on one hand a metal fence of $900 \mathrm{~m}$ around the hill of Tepe Narenj and around the X and XIV areas. They will help to protect the site from intrusion and unauthorized constructions.

If funding permits, it is proposed to make the entire site a museum that could be a strong point of cultural tourism in Kabul. Preservation and site development can also contribute to further education of the residents about the importance of their cultural heritage.

All of our eleven excavation campaigns, site protection, and consolidation of the sculptures were made with very modest financial means compared to those available to the French excavating in Bamiyan or Balkh (Bactres). In the coming years, we hope to continue our research on this monastic complex in order to clarify further the practice of Buddhism in the Kabul area and Buddhism in general in the southern part of Afghanistan, especially under the patronage of the Hephtalite Kingdom.

\footnotetext{
${ }^{14}$ The choice of using baked bricks for walls and metal beams was made on the advice of the masons.
} 


\section{BIBLIOGRAPHY}

J.Hackin, J.Carl and J.Meunié, Various archaeological research in Afghanistan (19331940), P 7-12, Paris, 1959.

D. Schlumberger and R. Curiel, monetary Treasures of Afghanistan, p. 129, Paris, 1953. G. Fussman Baba Murad, E. Ollivier, Buddhist Monument Kabul region, vol I, pp 80-81, Paris, 2008.

Z.Paiman, Renewal of Afghan archeology, Archéologia, No. 419, pp 30-32. Paris, 2005.

Z.Paiman 2005, 2006, 2008, 210, Archéologia, 419, 430, 461 and 473, p 33-39, 24$35,56-65$ and $52-59$.

History of Sistan, 1366/1987, p. 215-216 (Persian text).

Edward C. Sachau, Alberuni's India, vol, II, pp. 10-14. London. 1888.

Curel R. and D. Schlumberger, Monetary Treasures of Afghanistan, Paris, 1953.

N. Dupree, 1965 An historical guide to Kabul.

W. Ball and JC Gardin, Catalogue of archaeological sites in Afghanistan, Archaeological Gazetteer of Afghanistan, Paris, 1982.

C.Masson, Narrative of various journeys in Balochistan, Afghanistan, the Punjab \& Kalat, Vol III, London, 1844.

Z.Paiman Mr. Alram, Tepe Narenj Cabool or Buddhist art in Kabul at the time of Muslim incursions, Paris, College France, 2013.

G.Fussman Baba Murad and E. Ollivier, Buddhist Monuments in the Kabul area, Paris, Collège de France, 2008, vol. 1,

M.Bénisti, Study on the stupa in ancient India, Paris, BEFEO, t. L, Issue. 1, 1960.

Z. Tarzi, "Hadda in the light of the past three campaigns Excavations of Tepa-eShotor 1974." Academy of Inscriptions and Belles-Lettres. July-October 1976, pp. 406-407, 1976. 


\section{Figure Captions}

No. 00_ general plan Tepe Narenj, Zone X and XIV zone.

No. 1_zone III with five chapels during excavation.

No. 2_ Chapel 2 and the facade of the stupa.

No. 3 - overview of the Chapel 3 with the remains at the bottom of the Great Buddha, and the other six figures standing against the north and south walls.

No. 4_the chapel and the characters standing on the south side of the seat.

No. 5_ chapel XI zone: the central base and feet of a colossal statue.

No. 6 _ chapel area $8 \mathrm{X}$ Overview with the central base and the east side.

No. 7 preparation of the roof above the circular room (room homa).

No. 8 In the foreground view of zone III with the protection of a roof by five

chapels; basically, behind the zone III, the layout of the roof on the chapel 6 XI zone.

No. 9_ overview of Tepe hill Narenj the south. 


\section{Zafar Paiman}

Franco-Afghan archaeologist, excavation director Tepe Narenj.

Member of INRAP (National Institute for Preventive Archaeological Research).

Attached to the research department of Indian Civilization at the College of France.

Associate Researcher at the CNRS-ENS (UMR 8546) 